Recebido: 09-08-2017 Aceito: 16-03-2018 Publicado: 10-07-2018

\title{
Influence of toposequence position of Stryphnodendron adstringens trees on discrimination of samples based on spectroscopy
}

\author{
Silvana Nisgoski ${ }^{1 \star}$, Thais Alves Pereira Gonçalves ${ }^{2}$, Natalia Monfron de Oliveira ${ }^{3}$, Serena Cadorin \\ Bittencourt $^{3}$, Gabriela Sgarbi Lima ${ }^{3}$, Graciela Ines Bolzon de Muñiz ${ }^{1}$ \\ ${ }^{1}$ Departamento de Engenharia e Tecnologia Florestal, Universidade Federal do Paraná, Curitiba, PR, Brasil. \\ ${ }^{2}$ Museu Paraense Emílio Goeldi, Belém, PA, Brasil. \\ ${ }^{3}$ Engenharia Industrial Madeireira, Universidade Federal do Paraná, Curitiba, PR, Brasil.
}

\begin{abstract}
Stryphnodendron adstringens is a native species from Caatinga and Cerrado biomes. The chemical composition of species is variable and depends on the part of the tree, as well as on genetic and soil characteristics related to the origin of the population. This paper describes the influence of toposequence position of trees on the discrimination of wood and bark samples based on visible (VIS), near-infrared (NIR) and mid-infrared (MID) spectroscopy. A total of 28 trees were collected in the northern part of Cerrado State Park in the municipality of Jaguariaíva, Paraná state, Brazil, in different types of soil, at seven positions $(0,100,200,300,400,500$ and $600 \mathrm{~m})$ of the toposequence. The results showed the influence of the position of trees. The bark was classified as dark brown and the wood as rose-grey. VIS spectra was not efficient in sample discrimination. The Principal Component Analysis (PCA) of NIR spectra presented two groups that can be related to the the type of soil: (i) 0-300 m - Red-Yellow Latosol and Haplic Cambisol; (ii) 400-600 m - Red Latosol. MID infrared spectra of bark also showed the distinction of two previous groups; and analysis based on wood spectra of trees collected on $0-100 \mathrm{~m}$ presented discrimination from other positions.
\end{abstract}

Keywords: infrared; colorimetry; multivariate analysis; wood and bark distinction.

\section{Introduction}

Stryphnodendron adstringens (Mart.) Coville (Fabaceae Lindl), commonly known as barbatimão, is a native species from Caatinga and Cerrado biomes; it might be found in the states of Tocantins, Bahia, Goiás, Mato Grosso, Mato Grosso do Sul, Minas Gerais, São Paulo and Paraná, as well in the Federal District (SOUZA; LIMA, 2017). The species present its principal applications for medicinal purpose (FERREIRA et al., 2013). A review by Lima et al. (2016) described many composites from secondary metabolism of Stryphnodendron adstringens, such as alkaloids, terpenes, flavonoids, steroids and tannins, the last being the predominant constituent, adding therapeutic value to the species. The application of tannin extract in addition to bionanocomposites with natural antimicrobial properties (COSTA et al., 2013) against infections was also evaluated (LUIZ et al., 2015). In wood industry, tannin extracts from bark have been tested as adhesives in particleboards and OSB production (CARVALHO et al., 2014a, b).

The chemical composition of species is variable and depends on the part of the tree, as well as genetic and population origin. Intra-population genetic variability of Stryphnodendron adstringens from populations found in Cerrado regions, Goiás, Minas Gerais and São Paulo was found to be higher than inter-population diversity; and high tannin concentration in bark was related to lower percentage of polymorphic genes (MENDONÇA et al., 2012). Also, in samples from Minas Gerais, the total extractives content varied among branches (19.8\%), stems (20.66\%) and roots (26.8\%) (GOULART et al., 2012) and total phenolic content 
was $13.96 \%$ in leaves, $11.47 \%$ in bark and $2.35 \%$ in stems (MACEDO et al., 2007). Soil characteristics and season also have an influence on phenol and tannin yields. Jacobson et al. (2005) observed that the highest total phenols and tannins contents in Stryphnodendron spp. were associated with soils having low chemical fertility and were observed in the rainy season.

Correct knowledge of species is important for adequate final use in industry and for forest conservation. Therefore, fast analysis of variations is important, for which the use of nondestructive techniques such as visible an infrared spectroscopy can be an alternative.

Wood is produced by the vascular cambium by a complex sequence of interactions between gene-protein expression and the local environment (climate and nutritional factors, growth regulators and physical stresses), which varies continuously over time (DOWNES; DREW, 2008). Wood color differs among species and within a tree, e.g., heartwood and sapwood (DÜNISH et al., 2010; KILIC; NIEMZ, 2012) and is an important factor for final applications and cost. Also, it is influenced by soil, climate, age and silviculture management (LIU et al., 2005). Extractives vary between and within trees and are related to age, environmental conditions and soil, and some studies have found that the largest variations in wood color are associated with extractives content (GIERLINGER et al., 2004; AGUILAR et al., 2009; MOYA; BERROCAL, 2010).

Near-infrared (NIR) studies with wood samples for origin discrimination were described by Sandak et al. (2011), who found relations between the spectra and the origin of trees grown in different locations in Europe; Nisgoski et al. (2016b), who observed the sensitivity of near-infrared spectra in discrimination of six provenances of Criptomeria japonica growing in the same region; and Hwang et al. (2016), who studied pine species from different countries. The application of mid-infrared (MID) spectroscopy enabled the distinction of beech trees grown at different sites (RANA et al., 2008), types of wood-plastic composites (LEE et al., 2010), separation between species of the orders Fagales and Malpighiales (CARBALLO-MEILAN et al., 2014), suitability of wood species to make artistic objects (BUOSO et al., 2016), and characteristics of archeological wood (TRAORÉ et al., 2016), among others.

The above-mentioned information shows that environmental conditions have influence on the chemical composition of species, and knowledge about it is important for final industrial uses. The question is whether spectroscopy is accurate enough to discriminate trees growing in the same region but in different position of toposequence. So, in this paper it is proposed that techniques based on colorimetry/VIS, NIR and MID spectroscopy present sensibility to variations in seven toposequence positions and should be applicable to rapid discrimination of wood and bark samples from Stryphnodendron adstringens.

\section{Material and Methods}

\section{Material}

Trees were collected without identification of age in a natural strand, in the northern portion of Cerrado State Park in the municipality of Jaguariaíva (240ㅗ'S; 50¹8’W), Paraná state, Brazil (Figure 1), with a mixed geomorphic pattern (convex-divergent/concave-convergent). Soil characteristics were Red Latosol in the upper part of the slope, Red-Yellow Latosol in the middle part and Haplic Cambisol in the lower part (UHLMANN et al., 1997). Red Latosol and Red-Yellow Latosol are defined as distrofic, with low base saturation $(<50 \%)$ in most of the first $100 \mathrm{~cm}$ of $\mathrm{B}$ horizon (including BA); Haplic Cambisol present clay of low activity and the same low base saturation of the previous soil (EMBRAPA, 
2014). The climate in the region, based on Köppen classification, is subtropical temperate $(\mathrm{Cfb})$, with precipitation of 1400-1600 mm and mean temperature of 17 $19^{\circ} \mathrm{C}$ (ALVARES et al., 2013).

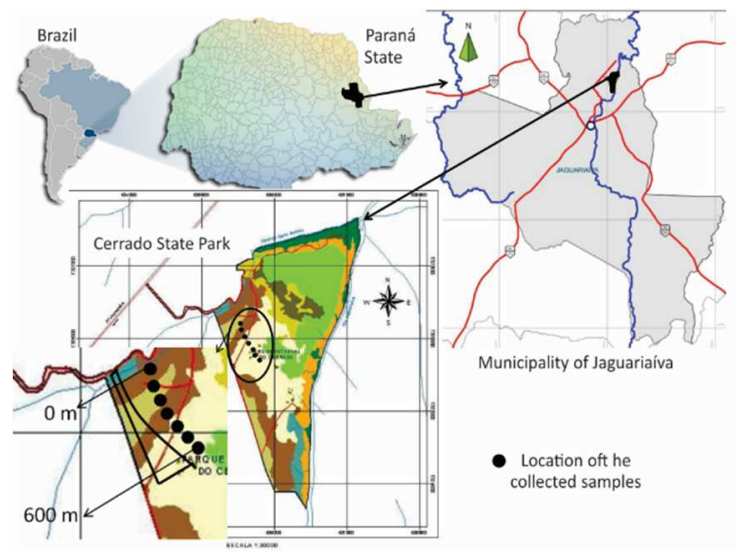

Figure 1. Location of the samples.

Figura 1. Localização das amostras.

For the selection of trees, a straight with $600 \mathrm{~m}$ was drawn in toposequence from downstream to upstream and seven points were marked $(0,100,200,300,400,500$ and $600 \mathrm{~m})$. In each point a transect line was drawn and four trees were collected at each of seven points of the toposequence (Figure 1 and Table 1). Wood and bark were obtained at breast height of each tree. Twenty-eight disks were air dried, transformed manually in chips and ground in a Wiley mill type. To avoid heating and changes in the material, an interval of 30 minutes between the grinding of each sample was established. The material was classified and the portion that passed through 60 meshes was analyzed.

\section{Methods}

The colorimetric evaluation was performed with a CM-5 spectrophotometer, with a spectral range from 350-750 nm, D65 light source and $10^{\circ}$ observation angle (CIE- $L^{*} a^{*} b^{*}$ standard). Data on lightness $\left(L^{\star}\right)$, green-red chromatic coordinate $\left(\mathrm{a}^{*}\right)$ and blue-yellow chromatic coordinate $\left(\mathrm{b}^{\star}\right)$ were obtained. The data were analyzed using descriptive statistics and regression analysis. The Tukey test was also performed to verify groups in function of toposequence position based on color parameters at $95 \%$ probability.

Table 1. Data from collected trees of Stryphnodendron adstringens.

Tabela 1. Dados das árvores coletadas de Stryphnodendron adstringens.

\begin{tabular}{|c|c|c|c|}
\hline $\begin{array}{c}\text { Toposequence } \\
(\mathbf{m})\end{array}$ & $\mathrm{H}(\mathrm{cm})$ & $\mathrm{DBH}(\mathrm{cm})$ & $\begin{array}{c}\text { Altitude } \\
(\mathrm{m})\end{array}$ \\
\hline 0 & 3.5 & 9.5 & 807 \\
\hline 0 & 4.5 & 16.6 & 807 \\
\hline 0 & 5.0 & 11.8 & 807 \\
\hline 0 & 4.5 & 18.8 & 807 \\
\hline 100 & 3.6 & 9.2 & 822 \\
\hline 100 & 3.0 & 5.7 & 822 \\
\hline 100 & 3.4 & 9.2 & 822 \\
\hline 100 & 3.2 & 8.3 & 822 \\
\hline 200 & 4.7 & 10.5 & 835 \\
\hline 200 & 3.8 & 8.6 & 835 \\
\hline 200 & 3.7 & 9.5 & 835 \\
\hline 200 & 4.4 & 11.8 & 835 \\
\hline 300 & 4.0 & 8.6 & 837 \\
\hline 300 & 3.9 & 8.6 & 837 \\
\hline 300 & 3.6 & 9.2 & 837 \\
\hline 300 & 4.0 & 11.1 & 837 \\
\hline 400 & 4.1 & 10.5 & 854 \\
\hline 400 & 4.3 & 8.9 & 854 \\
\hline 400 & 4.1 & 8.9 & 854 \\
\hline 400 & 4.6 & 8.0 & 854 \\
\hline 500 & 4.7 & 9.5 & 860 \\
\hline 500 & 4.8 & 9.5 & 860 \\
\hline 500 & 3.8 & 8.0 & 860 \\
\hline 500 & 4.3 & 8.3 & 860 \\
\hline 600 & 4.5 & 9.9 & 879 \\
\hline 600 & 3.9 & 12.7 & 879 \\
\hline 600 & 3.7 & 11.8 & 879 \\
\hline 600 & 5.5 & 14.6 & 879 \\
\hline
\end{tabular}

Infrared analyzes were performed with a Bruker Tensor 37 spectrometer equipped with an integrating sphere and operating in reflectance mode; 64 scans were averaged with resolution of $4 \mathrm{~cm}^{-1}$ and a spectral range of $10,000-400 \mathrm{~cm}^{-1}$. In a room with temperature of $23 \pm 2{ }^{\circ} \mathrm{C}$ and relative humidity 
of $60 \%$, the wood and bark samples were placed on top of the integrating sphere in a cuvette with diameter of $1 \mathrm{~cm}$.

The Unscrambler X chemometric program (version 10.1, from CAMO Software AS) was used to analyze the data. Exploratory modeling was done by analyzing the score and loading graphs obtained by principal component analysis (PCA), based on the NIPALS algorithm and cross validation, to check for possible differences in samples based on toposequence position. To eliminated or minimized additive and multiplicative scattering, pretreatment of first derivative (polynomial order $=1$, smoothing point $=2$ ) and second derivative of Savitzy-Golay (polynomial order $=2$, smoothing point $=3$ ) were applied to raw data. Spectral analysis was based on American Society for Testing and Materials - ASTM E1655-05 (ASTM, 2000).

\section{Results and Discussion}

\section{Colorimetry}

The colorimetric parameters of the samples collected from the seven positions in toposequence (Table 2) showed some differences. In bark, some distinction was observed in luminosity $\left(\mathrm{L}^{*}\right)$ at $500 \mathrm{~m}$, but not a tendency for changes in function of position in toposequence. In the green-red chromatic coordinate $\left(\mathrm{a}^{\star}\right)$, two groups were observed, one from $0-200 \mathrm{~m}$ and other from $300-600 \mathrm{~m}$. For intensity of the blue-yellow chromatic coordinate $\left(b^{\star}\right)$, there is no increase or decrease in function of position. For wood, colorimetric parameters were more homogeneous and did not present a tendency of grouping in function of geographic coordinates.

Based on a timber color chart (CAMARGOS; GONÇALEZ 2001), bark from Stryphnodendron adstringens was classified as dark brown and wood as rose-grey. The results agree with Amorim et al. (2013) who comment that the $\mathrm{a}^{*}$ coordinate is mainly responsible for the red color, whereas the $b^{*}$ coordinate influences the final color. The application of colorimetry for species identification must be done carefully (GARCIA et al., 2014) because color variation within a species is frequent and can be related to genetic and environmental characteristics (BRADBURY et al., 2011).

Significant differences in colorimetric parameters between species, provenances and sites were described by Gierlinger et al. (2004). Sotelo Montes et al. (2013) evaluating color among natural populations of five species in Mali, observed that all species presented variation with geographical coordinates, but the relationships differed among species, and that longitude and elevation generally were better explanations for the variation than latitude. Chemical characteristics of soil and its physical properties, rainfall and water availability can also affect wood color (BRADBURY et al., 2011; MOYA; CALVO-ALVARADO, 2012).

In a study with teak wood, Moya; Berrocal (2010) observed that the variation of extractives or chemical composition of lignin produced from diverse soils explained the variation of heartwood color in young teak, and wood color was the result of the combination of plantation characteristics. In another study, Moya; Calvo-Alvarado (2012) concluded that climatic variables should be considered as the first-order causal variables to explain wood color variation, and darker $\mathrm{b}^{\star}$ coordinate was associated with dry climates as well as with deeper and more fertile sites. The influence of high growth rate on the standard deviation of color parameters of Robinia varieties was detailed by Csordós et al. (2014), but mean values were not influenced in comparison with control samples that were not fast growing.

Phenolic content was associated to differences in origins and sites, and related to correlation coefficients between color coordinates, extractives and relative decay resistance (GIERLINGER et al., 2004). In Acacia mangium and Vochysia guatemalensis, color parameters and extractives and phenolic 
content (in hot water and ethanol-toluene extracts) for both species varied widely, especially the parameters $\mathrm{a}^{\star}$ and $\mathrm{b}^{\star}$, and the authors commented that one of the possible causes was the origin of the trees, which came from 30 different plantations located in two regions of Costa Rica (MOYA et al., 2012).
Reflectance curve of samples showed the similarity among all of them and principal component analysis (PCA) of visible spectra with different pretreatments was not able to distinguish bark samples based on position in toposequence. In wood, a tendency of grouping samples from 0-200 $\mathrm{m}$ was observed. Other samples did not present a similar trend.

Table 2. Mean and (standard deviation) of colorimetric parameters from Stryphnodendron adstringens bark and wood samples in seven toposequence positions.

Tabela 2. Média e (desvio padrão) dos parâmetros colorimétricos da madeira e casca de Stryphnodendron adstringens em sete posições na toposequência.

\begin{tabular}{|c|c|c|c|c|c|c|}
\hline \multirow{2}{*}{$\begin{array}{l}\text { Position } \\
\text { (m) }\end{array}$} & \multicolumn{3}{|c|}{ Bark } & \multicolumn{3}{|c|}{ Wood } \\
\hline & $\mathbf{L}^{*}$ & $\mathbf{a}^{*}$ & $\mathbf{b}^{*}$ & $\mathbf{L}^{*}$ & $\mathbf{a}^{\star}$ & $\mathbf{b}^{*}$ \\
\hline 0 & $37.92 \mathrm{a}(2.23)$ & $11.15 \mathrm{~b}(1.01)$ & $12.79 \mathrm{bc}(1.54)$ & 61.77 a $(2.70)$ & $9.59 \mathrm{~cd}(1.19)$ & $19.81 \mathrm{a}(1.80)$ \\
\hline 100 & 38.35 a (2.67) & $10.72 \mathrm{~b}(1.32)$ & 12.36 c (1.20) & $62.26 \mathrm{a}(1.82)$ & $9.02 \mathrm{~d}(1.09)$ & $19.62 \mathrm{a}(1.00)$ \\
\hline 200 & $36.26 \mathrm{ab}(1.67)$ & $10.90 \mathrm{~b}(0.99)$ & 11.98 c (1.22) & $62.01 \mathrm{a}(2.01)$ & $11.08 \mathrm{~b}(0.78)$ & 17.13 c (0.58) \\
\hline 300 & $36.62 \mathrm{ab}(1.78)$ & $11.01 \mathrm{~b}(0.93)$ & $13.13 \mathrm{bc}(1.28)$ & $61.01 \mathrm{ab}(8.84)$ & $10.27 \mathrm{bc}(1.66)$ & $18.02 \mathrm{bc}(1.50)$ \\
\hline 400 & $37.15 \mathrm{ab}(1.94)$ & $12.97 \mathrm{a}(0.93)$ & $14.16 \mathrm{ab}(1.40)$ & $63.40 \mathrm{a}(2.40)$ & $10.80 \mathrm{~b}(0.73)$ & 17.19 c $(0.75)$ \\
\hline 500 & $35.31 \mathrm{~b}(1.77)$ & $12.60 \mathrm{a}(0.85)$ & $13.75 \mathrm{ab}(1.15)$ & $62.44 \mathrm{a}(3.72)$ & $10.44 \mathrm{bc}(1.04)$ & $18.12 \mathrm{bc}(1.17)$ \\
\hline 600 & $37.09 \mathrm{ab}(1.89)$ & $12.38 \mathrm{a}(0.55)$ & $14.81 \mathrm{a}(1.13)$ & $58.34 \mathrm{~b}(1.35)$ & $13.47 \mathrm{a}(1.22)$ & $18.71 \mathrm{ab}(0.71)$ \\
\hline
\end{tabular}

Mean values followed by the same letter in the same column do not differ statistically by the Tukey test at $95 \%$ probability; $\mathrm{L}^{*}=$ lightness, $\mathrm{a}^{*}=$ green-red chromatic coordinate and $\mathrm{b}^{*}=$ blue-yellow chromatic coordinate

\section{NIR spectroscopy}

The NIR spectra of all samples were similar, and to eliminate noise and remove additive and multiplicative effects in the spectra, as well as to improve analysis, the first and second derivatives were applied. PCA was carried out to verify the distribution of wood samples. PCA analysis (Figure 2) with derivatives showed two groups: 0-300 m and 400-600 $\mathrm{m}$. The grouping is probably related to soil characteristics and distance from water-bearing strata. The soil in the 0-300 m range is classified as Red-Yellow Latosol and Haplic Cambisol, whereas that from $400-600 \mathrm{~m}$ is Red Latosol.

Environmental conditions can affect tree growth and wood chemical composition, which are reflected in spectra (SANDAK et al., 2011; HWANG et al., 2016; NISGOSKI et al., 2016a). Soil characteristics, such as nutrient availability, physical properties and carbon content, can also influence tree growth and wood properties (BALIGAR et al., 2007; FAGERIA, 2012). In a study with six provenances of Criptomeria japonica planted in the same region, nearinfrared analysis was able to discriminate them (NISGOSKI et al., 2016b), whereas in an experiment of different fertilization in pines species, the influence of individual tree was more evident than that of the treatment (NISGOSKI et al., 2016a).

In the NIR spectra, some bands presented difference between group $1(100-300 \mathrm{~m})$ and group $2(400-600 \mathrm{~m})$ : bands at $6339,6270,6287,6476,7460,7481,7547,7562,8156$, $8411,8446,8450,8463,8469,8496$ and $8750-8760 \mathrm{~cm}^{-1}$. These regions are related to cell wall composition and some phenolic compounds (SCHWANNINGER et al., 2011). In some regions, there is a peak dislocation and in other regions the difference is related to the presence of peaks. Sandak et al. (2011) observed the influence of the environmental factors of 
the origin of samples and the influence of altitude in sample discrimination. Different exposure at the same altitude can also influence NIR spectra. Hwang et al. (2016) showed the distinction of Pinus sylvestris growing in two countries and $P$. densiflora from South Korea.

\section{MID spectroscopy}

MID infrared spectra from bark (Figure 3) and wood (Figure 4) showed little distinction based on position in toposequence. In bark, bands at $669,898,900,952,990,1014$, $1097,1104,1122,1146,1158,1246,1375,1425,1462$ and 1650 $\mathrm{cm}^{-1}$ are related to variations in the components pectin, cellulose, hemicelluloses and lignin (RANA et al., 2008; LARGO-GOSENS et al., 2014). They presented variations but
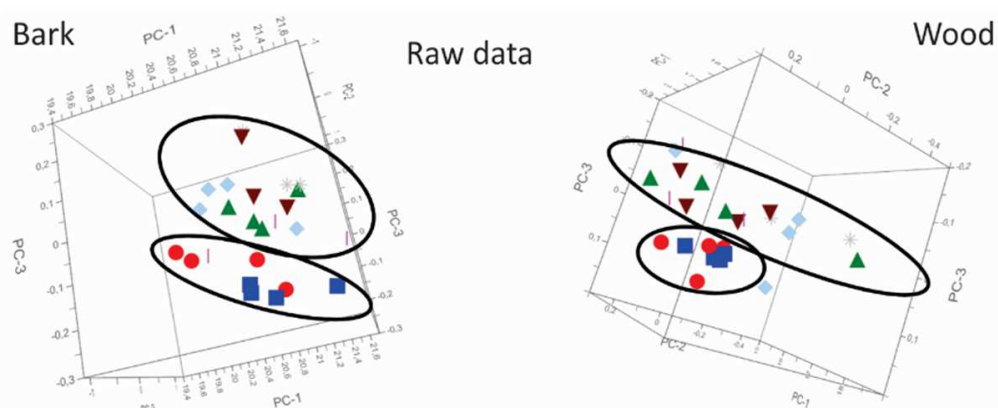

1st derivative
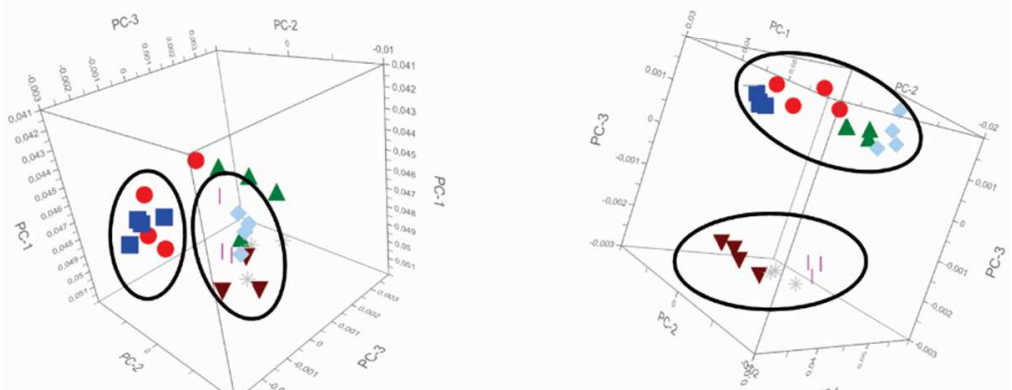

2nd derivative
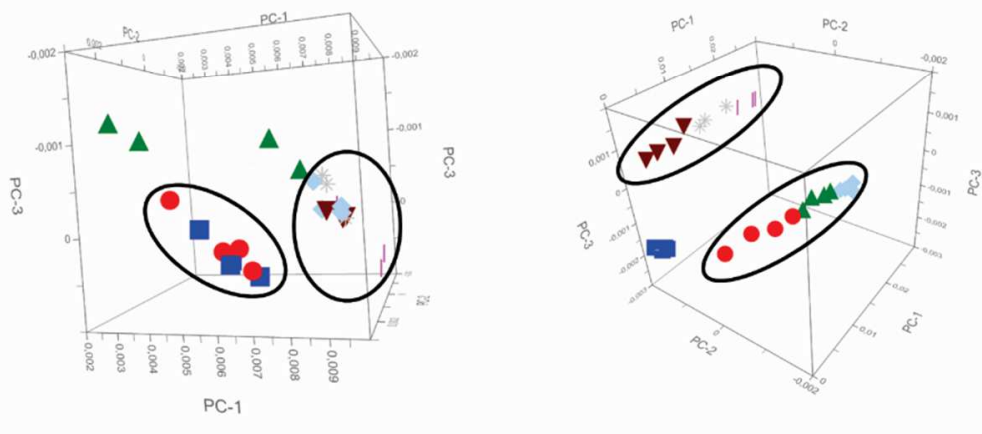

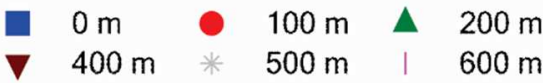

Figure 2. PCA from NIR spectra of Stryphnodendron adstringens bark and wood samples in seven positions in toposequence with different pretreatments.

Figura 2. PCA dos espectros NIR da madeira e casca de Stryphnodendron adstringens em sete posições na toposequência com diferentes pré-tratamentos. 
not a pattern related to toposequence position. Bands at 1550 and $1650 \mathrm{~cm}^{-1}$ are related to protein content in the cell wall, and the bands in the regions near $1510 \mathrm{~cm}^{-1}$ and $1530-1540$ $\mathrm{cm}^{-1}$ are attributed to lignin (LARGO-GOSENS et al., 2014), showing groups from $0-200 \mathrm{~m}$ and $300-600 \mathrm{~m}$. The region from $1400-1442 \mathrm{~cm}^{-1}$ was related to phenolic contents, resulting in two groups based on position: with $0-200 \mathrm{~m}$ and $400-500 \mathrm{~m}$; other samples from 300 and $600 \mathrm{~m}$ presented no pattern. Regions at 1040, 1041 and $1043 \mathrm{~cm}^{-1}$ were related to cellulose, xyloglucan and arabinogalactan, respectively (LARGO-GOSENS et al., 2014) and showed other conformation: 100 to $300 \mathrm{~m}$ and 400 to $600 \mathrm{~m}$. This result was also observed at $1030 \mathrm{~cm}^{-1}$ attributed to aromatic $\mathrm{C}-\mathrm{H}$ plane deformation (RANA et al., 2008).

In wood, some differences were observed in bands at 669 , $898,1030,1158,1330,1375,1525-1579,1597-1676 \mathrm{~cm}^{-1}$, related to variations in wood components pectin, cellulose, hemicelluloses and lignin (RANA et al., 2008; LARGOGOSENS et al., 2014), but there was no linear pattern related to toposequence position.

For species discrimination, Buoso et al. (2016) related diferent peaks attributed to each species in a study of Populus spp. (771 and $\left.1607 \mathrm{~cm}^{-1}\right)$, Tilia spp. and Betula spp. (1690$1800 \mathrm{~cm}^{-1}$ and $\left.1200-1300 \mathrm{~cm}^{-1}\right)$, and bands attributed to chemical composition of cell wall. The influence of growing at an inclined angle on wood chemical composition was evaluated by Shi et al. (2012), who observed an increase in relative intensity of bands at $1232,1267,1457$ and $1510 \mathrm{~cm}^{-1}$ and a decrease in bands at 1160,1371 and $1739 \mathrm{~cm}^{-1}$.

In bark and wood of Stryphnodendron adstringens, the region from 2258 to $2387 \mathrm{~cm}^{-1}$ showed variation between toposequence positions. These bands are attributed to $\mathrm{CO}_{2}$ and are influenced by atmospheric conditions on spectra acquisition.
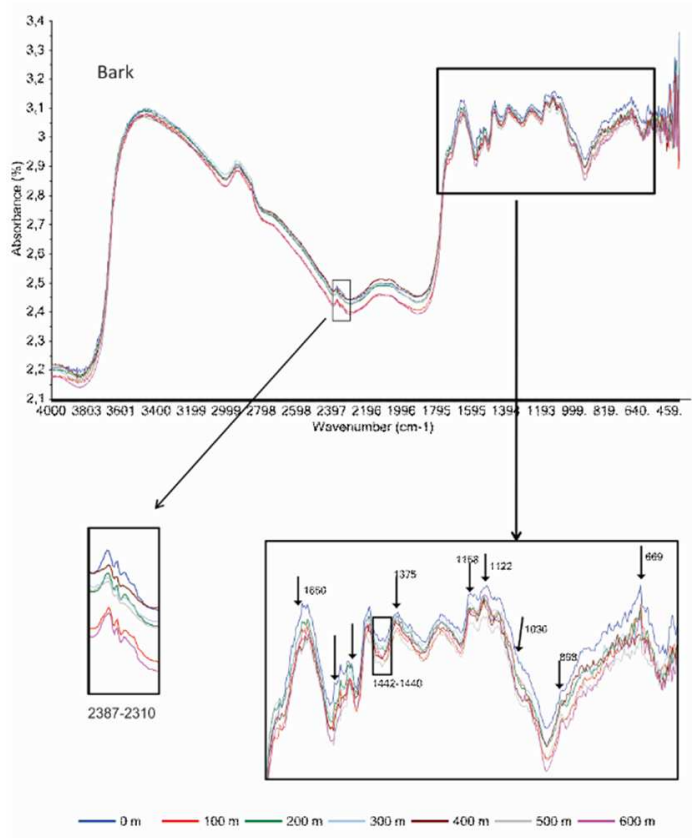

Figure 3. MID infrared spectra of bark samples of Stryphnodendron adstringens in seven positions in toposequence.

Figura 3. Espectros em infravermelho médio da casca de Stryphnodendron adstringens em sete posições na toposequência.

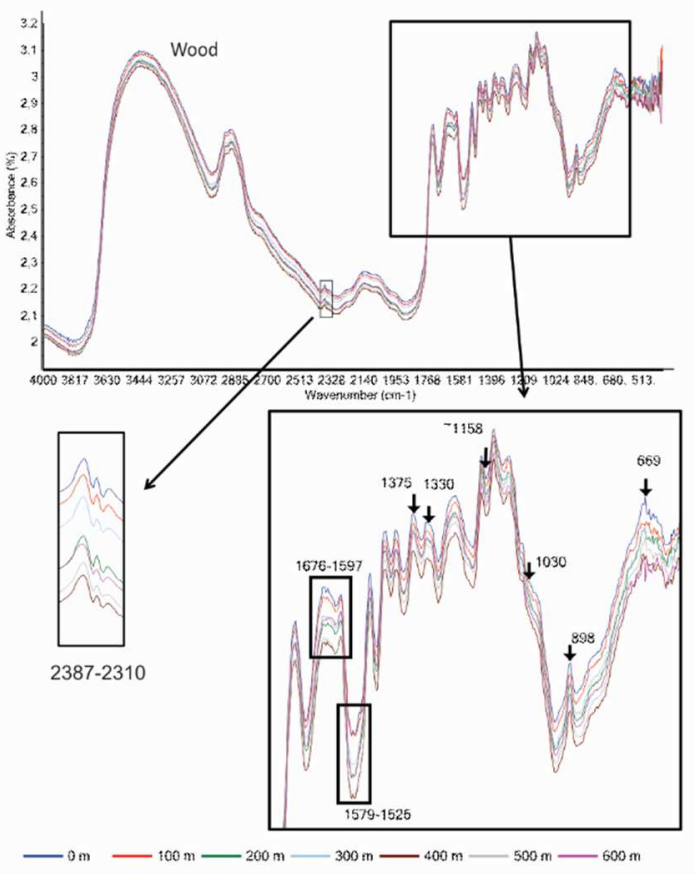

Figure 4. MID infrared spectra of wood samples of Stryphnodendron adstringens in seven positions in toposequence.

Figura 4. Espectros em infravermelho médio da madeira de Stryphnodendron adstringens em sete posições na toposequência. 
PCA with total MID spectra was not able to distinguish different positions of trees in toposequence. So, the analysis was performed with different regions with more contrast in wood $\left(1550-1750 \mathrm{~cm}^{-1}\right)$ and bark (600-1700 $\left.\mathrm{cm}^{-1}\right)$ (Figure 5). In bark, PCA with original data grouped trees from 0-100 m and from 200-600 m; in case of derivatives, the groups were 0-200 $\mathrm{m}$ and 300-500 m. For wood, samples from 0-100 m and 200-600 $\mathrm{m}$ showed similar grouping in raw data and with derivatives. The chemical composition must be evaluated to verify what is influencing in this grouping; it might also be the results of difference in soil characteristics or the proximity of water, which must be confirmed.
For samples of Stryphnodendron adstringens wood and bark, different regions presented the best information for discrimination of trees collected at different positions in toposequence. Rana et al. (2008), evaluating Fagus silvatica trees growing at five different sites, observed the potential of FTIR to distinguish wood in combination of multivariate statistical methods. The authors commented that the formations of groups were probably related to a combination of climatic factors and soil properties, and the most important bands to discriminate sites were assigned to ring vibration of carbohydrates and aromatics.

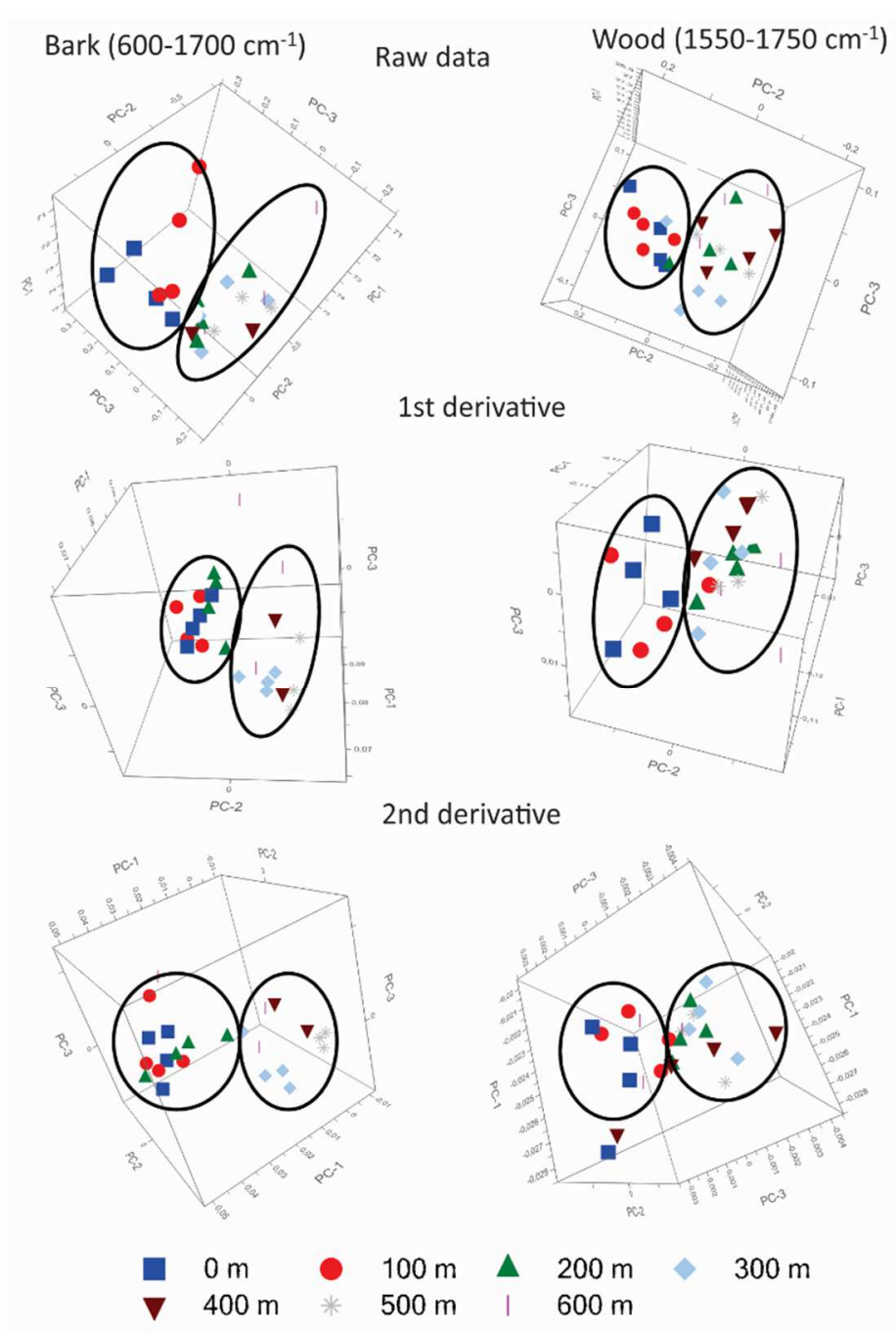

Figure 5. PCA in MID spectra of Stryphnodendron adstringens bark and wood samples in seven toposequence positions with different pretreatments.

Figura 5. PCA dos espectros MID da madeira e casca de Stryphnodendron adstringens em sete posições na toposequência com diferentes pré-tratamentos. 
Acquah et al. (2016) also applied FTIR spectroscopy with PCA and LDA to identify plant part composition of forest logging residue from loblolly pine and observed that the preliminary separation was performed in function of lignin and polysaccharide concentration. Largo-Gosens et al. (2014) presented a review of FTIR applications in studies with cell wall and described its application for discrimination of wood species and determination of chemical wood composition. The authors stated that although the technique presents many advantages over traditional analysis, it is not usually employed alone to analyze cell walls, but to confirm the results obtained with other chemical methods because the information from MID spectra is complex and there are overlapping peaks.

Santoni et al. (2015) discriminated Picea abies from three origins and commented that chemical and physical properties of samples were different, and the success of MID spectroscopy was related to differences in the molecular configuration of lignin with some contribution of cellulose and hemicelluloses. Carballo-Meilan et al. (2016) also attributed the differences between five gymnosperm trees and 16 angiosperm trees (from the Rosids and Asterids class) to their lignin and hemicelluloses content and observed some influence of amide.

\section{Conclusions}

The position of tree in a toposequence presented influence in VIS, NIR and MID spectra from wood and bark. VIS spectra was not efficient in sample discrimination. NIR spectroscopy presented the best potential to discriminate wood and bark from Stryphnodendron adstringens in samples obtained from different positions. MID infrared spectra of bark showed the distinction of two groups (0-300 $\mathrm{m}$ and 400$600 \mathrm{~m}$ ) and wood presented discrimination of trees collected on $0-100 \mathrm{~m}$ from other positions.

\section{References}

ACQUAH, G.E.; VIA, B.K.; BILLOR, N.; FASINA, O.O.; ECKHARDT L.G. Identifying plant part composition of forest logging residue using infrared spectral data and linear discriminant analysis. Sensors, v.16, n.9, p.1375, 2016.

AGUILAR, D.; MOYA, R.; TENORIO, C. Wood color variation in undried and kiln-dried plantation-grown lumber of Vochysia guatemalensis. Maderas. Ciencia y Tecnologia, v.11, n.3, p.207-216, 2009.

ALVARES, C.A.; STAPE, J.L.; SENTELHAS, P.C.; GONÇALVES, J.L.M.; SPAROVEK, G. Köppen's climate classification map for Brazil. Meteorologische Zeitschrift, v.22, n.6, p.711-728, 2013.

AMORIM, P.G.R.; GONÇALEZ, J.C.; CARMARGOS, J.A.A. Propriedades da madeira de Eucalyptus grandis e Pinus caribaea estimadas por colorimetria. Cerne, v.19, n.3, p.461$466,2013$.

ASTM. AMERICAN SOCIETY FOR TESTING AND MATERIALS. ASTM E1655-05 - Standard practices for infrared multivariate, quantitative analysis. Vol.03.06. West Conshohocken, Pennsylvania, USA, 2000.

BALIGAR, V.C.; FAGERIA, N.K.; HE, Z.L. Nutrient use efficiency in plants. Communications in Soil Science and Plant Analysis, v.32, n.7-8, p.921-950, 2007.

BRADBURY, G.; POTTS, B.M.; BEADLE, C.L.; DUTKOWSKI, G.; HAMILTON, M. Genetic and environmental variation in heartwood colour of Australian blackwood (Acacia melanoxylon R.Br.). Holzforschung, v.65, n.3, p.349-359, 2011.

BUOSO, M.C.; DE POLI, M.; MATTHAES, P.; SILVESTRIN, L.; ZAFIROPOULOS, D. Nondestructive wood discrimination: FTIR - Fourier Transform Infrared Spectroscopy in the characterization of different wood species used for artistic objects. Applications of Nuclear Techniques (CRETE15). International Journal of Modern Physics: Conference Series, v.44, p.1660212, 2016.

CAMARGOS, J.A.A.; GONÇALEZ, J.C. A colorimetria aplicada como instrumento na elaboração de uma tabela de cores de madeira. Brasil Florestal, n.71, p.30-41, 2001.

CARBALLO-MEILAN, A.; GOODMAN, A.M.; BARON, M.G.; GONZALEZ-RODRIGUEZ, J. A specific case in the classification of woods by FTIR and chemometric: 
discrimination of Fagales from Malpighiales. Cellulose, v.21, n.1, p.261-273, 2014.

CARBALLO-MEILAN, A.; GOODMAN, A.M.; BARON, M.G.; GONZALEZ-RODRIGUEZ, J. Application of chemometric analysis to infrared spectroscopy for the identification of wood origin. Cellulose, v.23, n.1, p.901-913, 2016.

CARVALHO, A.G.; ZANUNCIO, A.J.V.; MENDES, R.F.; MORI, F.A.; SILVA, M.G.; MENDES, L.M. Adesivos tânicos de Stryphnodendron adstringens (Mart.) Coville na produção de painéis aglomerados. Revista Árvore, v.38, n.1, p.195-202, 2014a.

CARVALHO, A.G.; MORI, F.A.; MENDES, R.F.; ZANUNCIO, A.J.V.; SILVA, M.G.; MENDES, L.M.; MORI, C.L.S.O. Use of tannin adhesive from Stryphnodendron adstringens (Mart.) Coville in the production of OSB panels. European Journal of Wood Products, v.72, n.4, p.425-432, $2014 b$

COSTA, L.M.M.; OLYVEIRA, G.M.; CHERIAN, B.M.; LEAO, A.L.; SOUXA, S.F.; FERREIRA, M. Bionanocomposites from electrospun PVA/pineapple nanofibers/Stryphnodendron adstringens bark extract for medical applications. Industrial Crops and Products, v.41, p.198-202, 2013.

CSORDÓS, D.; NÉMETH, R.; BAK, M. Variation of colour properties between and within new Robinia varieties with enhanced growing rates from different sites. BioResources, v.9, n.4, p.7099-7108, 2014.

DOWNES, G.M.; DREW, D.M. Climate and growth influences on wood formation and utilization. Southern Forests, v.70, n.2, p.155-167, 2008.

DÜNISCH, O.; RICHTER, H.G.; KOCH, G. Wood properties of juvenile and mature heartwood in Robinia pseudoacacia L. Wood Science and Technology, v.44, n.2, p.301-313, 2010.

EMBRAPA - Empresa Brasileira de Pesquisa Agropecuária. Sistema brasileiro de classificação de solos. 4. ed. Brasília, DF: EMBRAPA, 2014. E-book 376p.

FAGERIA, N.K. Role of soil organic matter in maintaining sustainability of cropping systems. Communications in Soil Science and Plant Analysis, v.43, n.16, p.2063-2113, 2012. FERREIRA, E.C.; SILVA, J.L.L.; SOUZA, R.F. Medicinal and biochemical properties of Stryphnodendron adstringens "barbatimão". Perspectivas on line: biologia \& Saúde, v.11, n.3, p.14-32, 2013.

GARCIA, R.A.; OLIVEIRA, N.S.; NASCIMENTO, A.M.; SOUZA, N.D. Colorimetria de madeiras dos gêneros Eucalyptus e Corymbia e sua correlação com a densidade. Cerne, v.20, n.4, p.509-517, 2014.

GIERLINGER, N.; JACQUES, D.; GRABNER, M.; WIMMER, R.; SCHWANNINGER, M.; ROZENBERG, P.; PÂQUES, L.E. Colour of larch heartwood and relationships to extractives and brown-rot decay resistance. Trees, v.18, n.1, p.102-108, 2004.

GOULART, S.L.; MORI, F.A.; RIBEIRO, A.O.; COUTO, A.M.; ARANTES, M.D.C.; MENDES, L.M. Análises químicas e densidade básica da madeira de raiz, fuste e galho de barbatimão [(Stryphnodendron adstringens) Coville] de bioma cerrado. Cerne, v.18, n.1, p.59-66, 2012.

HWANG, S.W.; HORIKAWA, Y.; LEE, W.H.; SUGIYAMA, J. Identification of Pinus species related to historic architecture in Korea using NIR chemometric approaches. Journal of Wood Science, v.62, n.2, p.156-167, 2016.

JACOBSON, T.K.B.; GARCIA, J.; SANTOS, S.C.; DUARTE, J.B.; FARIAS, J.G.; KLIEMANN, H.J. Influência de fatores edáficos na produção de fenóis totais e taninos de duas espécies de barbatimão (Stryphnodendron sp.). Pesquisa Agropecuária Tropical, v.35, n.3, p.163-169, 2005.

KILIC, A.; NIEMZ, P. Extractives in some tropical woods. European Journal of Wood Products, v.70, n.1-3, p.79-83, 2012.

LARGO-GOSENS, A.; HERÁNDEZ-ALTAMIRANO, M.; GARCÍA-CALVO, L.; ALONSO-SIMÓN, A.; ÁLVAREZ, J.; ACEBES, J.L. Fourier transform mid infrared spectroscopy applications for monitoring the structural plasticity of plant cell walls. Frontiers in Plant Science: Plant Biophysics and Modeling, v.5, article 303, 2014.

LEE, C.H.; WU, T.L.; CHEN, Y.L.; WU, J.H. Characteristics and discrimination of five types of woodplastic composites by FTIR spectroscopy combined with principal component analysis. Holzforschung, v.64, n.6, p. 699-704, 2010.

LIMA, T.C.D. DE; CARDOSO, M.V.; MODESTO, T.; OLIVEIRA, A.L. DE B.; SILVA, M.N. DA; MONTEIRO, M.C. Brief review ethnobotany, phytochemistry and pharmacology of Stryphnodendron adstringens used in the Amazon. Revista Fitos, v.10, n.3, p.220-372, 2016. 
LIU, S.; LOUP, C.; GRIL, J.; DUMONCEAUD, O.; THIBAUT, A.; THIBAUT, B. Studies on European beech (Fagus sylvatica L.). Part 1. Variations of wood color parameters. Annals of Forest Science, v.62, n.7, p.625-632, 2005.

LUIZ, R.L.F.; MACHADO, T.V.; MELLO, J.C.P.; NAKAMURA, C.V., ROZENTAL, S. ISHIDA, K. Proanthocyanidins polymeric tannin from Stryphnodendron adstringens are active against Candida albicans biofilms. BMC Complementary and Alternative Medicine, v.15, n.68, 2015.

MACEDO, F.M.; MARTINS, G.T.; MENDES, C.S.O.; SILVA, C.M.; RODRIGUES, C.G.; OLIVEIRA, D.A. Determinação de compostos fenólicos totais em barbatimão [Stryphnodendron adstringens (Mart) Coville]. Revista Brasileira de Biociências, v.5, supl. 2, p.1164-1165, 2007.

MENDONÇA, P.C.; BERTONI, B.W.; AMUI, S.F.; GIULIATTI, S.; CORRÊA, V.S.C.; FRANÇA, S.C.; PEREIRA, A.M.S. Genetic diversity of Stryphnodendron adstringens (Mart.) Coville determined by AFLP molecular markers. Biochemical Systematics and Ecology, v.41, p.16-20, 2012.

MOYA, R.; BERROCAL, A. Wood color variation in sapwood and heartwood of young trees of Tectona grandis and its relationship with plantation characteristics, site and decay resistance. Annals of Forest Science, v.67, n.1, p.109, 2010.

MOYA, R.; CALVO-ALVARADO, J. Variation of wood color parameters of Tectona grandis and its relationship with physical environmental factors. Annals of Forest Science, v.69, n.8, p.947-959, 2012.

MOYA, R.; SOTO FALLAS, R.; JIMÉNEZ BONILLA, P.; TENORIO, C. Relationship between wood color parameters measured by CIELAB system and extractive and phenol content of Acacia mangium and Vochysia guatemalensis from fast growth plantations. Molecules, v.17, n.4, p.3639-3652, 2012.

NISGOSKI, S.; KLOCK, U.; BATISTA, F.R.R.; SCHARDOSIN, F.Z.; CONSALTER, R.; MOTTA, A.C.V. Uso do NIR na discriminação de árvores em diferentes adubações com base nos espectros da madeira e da casca. Ciência da Madeira, v.7, n.2, p.100-110, 2016a.

NISGOSKI, S.; SCHARDOSIN, F.Z.; BATISTA, F.R.R.; MUÑIZ, G.I.B.; CARNEIRO, M.E. Potential use of NIR spectroscopy to identify Criptomeria japonica varieties from southern Brazil. Wood Science and Technologoy, v.50, n.1, p.71-80, 2016b.

RANA, R., MULLER, G., NAUMANN, A., POLLE, A. FTIR spectroscopy in combination with principal component analysis or cluster analysis as a tool to distinguish beech (Fagus sylvatica L.) trees grown at different sites. Holzforschung, v.62, n.5, p.530-538, 2008.

SANDAK, A.; SANDAK, J.; NEGRI, M. Relationship between near-infrared (NIR) spectra and geographic provenance of timber. Wood Science and Technology, v.45, n.1, p.35-48, 2011.

SANTONI, I.; CALLONE, E.; SANDAK, A.; SANDAK, J.; DIRÈ, S. Solid state NMR and IR characterization of wood polymer structure in relation to tree provenance. Carbohydrate Polymers, v.117, p.710-721, 2015.

SCHWANNINGER, M.; RODRIGUES, J.C.; FACKLER, K. A review of band assignments in near infrared spectra of wood and wood components. Journal of Near Infrared Spectroscopy, v.19, n.5, p.287-308, 2011.

SHI, J.; XING, D.; LI, J. FTIR Studies of the changes in wood chemistry from wood forming tissue under inclined treatment. Energy Procedia, v.16, part B, p.758-762, 2012.

SOUZA, V.C.; LIMA, A.G. Stryphnodendron. In: Flora do Brasil 2020 em construção. Jardim Botânico do Rio de Janeiro. 2017.

SOTELO MONTES, C.; WEBER, J.C.; GARCIA, R.A.; SILVA, D.A.; MUÑIZ, G.I.B. Variation in wood color among natural populations of five tree and shrub species in the Sahelian and Sudanian ecozones of Mali. Canadian Journal of Forest Research, v.43, n.6, p. 552-562, 2013.

TRAORÉ, M.; KAAL, J.; CORTIZAS, A.M. Application of FTIR spectroscopy to the characterization of archeological wood. Spectrochimica Acta Part A: Molecular and Biomolecular Spectroscopy, v.153, p.63-70, 2016.

UHLMANN. A.; CURCIO, G.R.; GALVÃO, F.; SILVA, S.M. Relações entre a distribuição de categorias fitofisionômicas e padrões geomórficos e pedológicos em uma área dc savana (cerrado) no Estado do Paraná. Brasil. Arquivos de Biologia e Tecnologia, v.4, n.2, p.473-484, 1997. 